\title{
Nutritive Value of Sperm Whale Oil and Finback Whale Oil.
}

\author{
By Yoshikazu SAHASEI. \\ (Received February 10, 1933.)
}

Though nutritional studies of fats or oils have already been carried out by many investigators, little is yet attempted in the feeding experiments with such oils as sperm whale oil which contains a large amount of waxes.

The present author, therefore, carried some feeding experiments of rats with synthetic diets containing large amounts of the oils obtained from sperm whale (Plyyseter macrocephalus L.) and finback whale (Baldenoptera physalus L.) for the purpose of contributing something to this nutrition problem.

Through the previous work of M. Tsujimoto ${ }^{(1)}$ and Y. Toyama ${ }^{(2)}$, the chemical properties of the oils prepared from sperm whale and finback whale have already been determined as follows:

\begin{tabular}{|c|c|c|c|}
\hline & $\begin{array}{l}\text { The head oil from } \\
\text { sperm whale } \\
\text { (M. Tsujimoto) }\end{array}$ & $\begin{array}{l}\text { The body oil from } \\
\text { sperm whale } \\
\text { (M. Tsujimoto) }\end{array}$ & $\begin{array}{l}\text { Finback whale } \\
\text { oil } \\
\text { (Y. Toyama) }\end{array}$ \\
\hline Sp. gr. & $d_{4}^{15}=0.8848$ & $d_{4}^{20}=0.8806$ & $d_{4}^{15}=0.9231$ \\
\hline Refr. index & $n_{\mathrm{D}}^{20}=1.4633$ & $n_{D}^{30}=1.4620$ & $n_{\mathrm{D}}^{40}=1.4727$ \\
\hline Acid value & 0.99 & 1.24 & 2.21 \\
\hline Saponification value & 147.1 & 131.6 & 196.6 \\
\hline Iodine value & 71.4 & 82.4 & 112.9 \\
\hline Reichert-Meissej value & 0.57 & - & - \\
\hline Unsaponifable matter & $36.0 \%$ & $36.4 \%$ & $1.09 \%$ \\
\hline Fatty acids & $65.0 \%$ & $64.13 \%$ & - \\
\hline Glycerol & $3.52 \%$ & - & - \\
\hline Cholesterol & $0.18 \%$ & & \\
\hline
\end{tabular}

The sperm whale oils consisted chiefly of mixed waxes. The unsaponifiable matter (wax alcohols) contains cetyl alcohol and oleic alcohol in nearly equal proportion. Small amounts of octadecyl and tetradecyl alcohol appear to be present. The total percentage of cholesterol was found to be $0.18 \%$ of the sperm oil. The fatty acids consisted of about $19 \%$ solid and about $81 \%$ of liquid acids. Among the solid (saturated) acids palmitic and miristic have been identified. A small quantity of caprylic or capric acids was also present. The liquid (unsaturated) acid consisted mainly of the oleic acids series : physetoleic and oleic acids. Not more than $1 \%$ of highly unsaturated acids was also present. On the contrary, the finback whale oils contained fatty acids of the same composition which occur in other animal or vegetable 
oils as common glycerides.

The present author carried out feeding experiments with a genuine head oil and an intestine oil obtained from sperm whale (male : body length about 14 meters) and with a blubber oil and an intestine oil prepared from a finback whale. These samples were kindly supplied from Tōyō Hogei Kaisha.

\section{Experimental.}

(1) Experiments with diets containing whale oils in sufficient quantity.

The analysis of the samples used in the experiments:

\begin{tabular}{l|c|c|c|c}
\hline & \multicolumn{2}{|c|}{ Sperm whale } & \multicolumn{2}{c}{. Finback whale } \\
\cline { 2 - 5 } & The head vil & The intestine oil & The ulubber oil & The intestine oil \\
\hline Sp. gr. & - & - & $d_{+}^{15}=0.916$ & $d_{4}^{15}=0.916$ \\
Refr. index & - & $n_{\mathrm{D}}^{25}=1.464$ & $n_{\mathrm{D}}^{22}=1.466$ & $n_{\mathrm{D}}^{22}=1.467$ \\
Acid value & 0.9 & 2.0 & 0.2 & 0.9 \\
Sap. value & 145.4 & 144.4 & 185.5 & 180.5 \\
Iod. value & 62.7 & 88.6 & 92.7 & 97.6 \\
Vitamin A & - & - & - & \\
\hline
\end{tabular}

For the experiments: Albino rats weighing $40 \sim 50 \mathrm{~g}$ each, were previously fed for several days on a complete diet until they reached $50 \sim 60 \mathrm{~g}$. Then they were divided into several groups, each consisting of four animals, and were fed on various experimental synthetic diets. (Fig. 1 8)

The diets consisted of :

Putato starch (Japanese Pharmacopoea IV)

Fish meat protein (bonito meat freed from fat)

McCollum's salt mixture

Oryzanin solution (Sankyo \& $\mathrm{Co}_{\text {. }}$ )

Dried yeast (supplied from Oriental Company extracted with ether)

Whale oils

Biosterin, dissolved in olive oil, given per os daily.

\begin{tabular}{|c|c|}
\hline $65 \mathrm{~g}$ & $60 \mathrm{~g}$ \\
\hline $15 \prime \prime$ & $15^{\prime \prime}$ \\
\hline $4^{\prime \prime}$ & $4 \prime \prime$ \\
\hline $5 \mathrm{cc}$ & - \\
\hline & $20 \mathrm{~g}$ \\
\hline
\end{tabular}

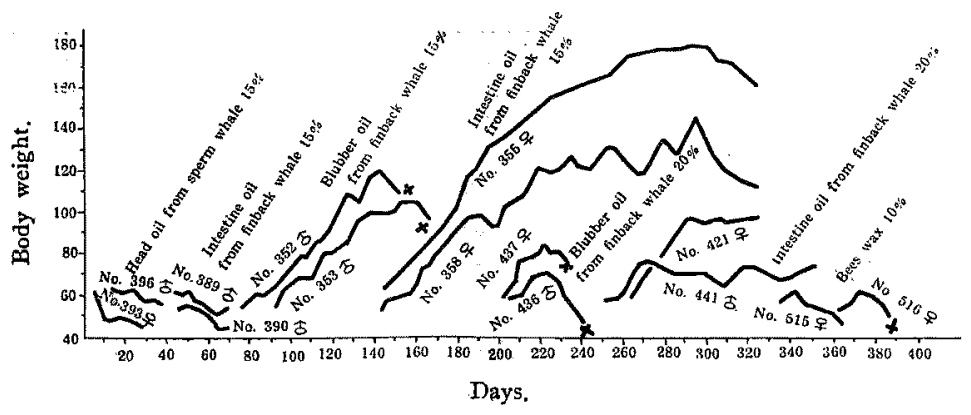

Fig: 1. The growth curves of the rats fed on diets containing whale oils. 
(II) Experiments with waxes and purified sperm oils,

In order to investigate the characteristic symptom of rats fed on the diets containing sperm oils as described above, the author attempted to purify the waxes from sperm oils.

i) Spermaceti (cetin): When the head oil from sperm whale was cooled at $0 \sim 5^{\circ} \mathrm{C}$, a large quantity of the solid wax which consisted chiefly of cetin separated at the bottom as white crystalline mass. It was collected, freed from the mother liquor (so-called winter sperm oil) by centrifugal machine, and recrystallized from hot alcohol.

ii) Liquid waxes: $100 \mathrm{~g}$ said winter sperm oils freed from the above solid waxes were boiled with 400 c.c. of a $3 \% \mathrm{Na}_{2} \mathrm{CO}_{3}$ solution for 3 hours. The impurities in the oils are thus completely dissolved. After cooling, the liquid oils were separated and washed with water until the wash water contained no trace of sodium carbonate. Analysis of waxes :

\begin{tabular}{l|c|c|c|c}
\hline & Solid waxes & \multicolumn{3}{|c}{ Liquid waxes } \\
\cline { 2 - 5 } & $\begin{array}{c}\text { Spermaceti } \\
\text { (cetin) } \\
\text { (head oil) }\end{array}$ & $\begin{array}{c}\text { Winter sperm } \\
\text { oil, freed from } \\
\text { spernaceti } \\
\text { (head oil) }\end{array}$ & $\begin{array}{c}\text { Winter sperm } \\
\text { oil, treated with } \\
\mathrm{Na}_{2} \mathrm{CO}_{3} \\
\text { (head oil) }\end{array}$ & $\begin{array}{c}\text { Winter sperm } \\
\text { oil, treated } \\
\text { with } \mathrm{Na}_{2} \mathrm{CO}_{\mathrm{S}} \\
\text { (intestine oil) }\end{array}$ \\
\hline Sp. gr. & - & $d_{4}^{15}=0.887$ & $d_{4}^{15}=0.856$ & $d_{4}^{15}=0.917$ \\
Refr. index & - & $n_{\mathrm{D}}^{26}=1.459$ & $n_{\mathrm{D}}^{26}=1.460$ & $n_{\mathrm{D}}^{25}=1.470$ \\
Acid value & 0 & 0.5 & 0.2 & 0.2 \\
Sap. value & 135.3 & 152.8 & 153.4 & 148.3 \\
lod. value & 17.0 & 76.9 & 66.2 & 90.6 \\
\hline
\end{tabular}

iii) Finback whale oils purified with $\mathrm{Na}_{2} \mathrm{CO}_{3}$ : The analysis of the samples treated with $\mathrm{Na}_{2} \mathrm{CO}_{3}$ in the above method (ii):

\begin{tabular}{l|c|c}
\hline \hline \multirow{2}{*}{} & \multicolumn{2}{|c}{ Purified finback whale oils } \\
\cline { 2 - 3 } & The blubber oil & The intestine oil \\
\hline Sp. gr. & $d_{4}^{15}=0.919$ & $d^{15}=0.918$ \\
Refr. index & $n_{\mathrm{D}}^{28}=1.474$ & $n_{\mathrm{D}}^{28}=1.474$ \\
Acid value & 0.2 & 0.2 \\
Sap. value & 184.3 & 182.5 \\
Iod. value & 93.0 & 102.5 \\
\hline
\end{tabular}

The results indicated that the glycerides are not destroyed.

Feeding experiments : Feeding experiments were carried out in the similar manner as described above. The diets consisted of: 
Potato starch (J. P. IV.)

Fish meat protein (bonito meat)

McCollum's salt mixture

Yeast as $d$ scribed above

Oryzanin sulution

Waxes prepared as described above

Biosterìn dissolved in olive oil per os daily
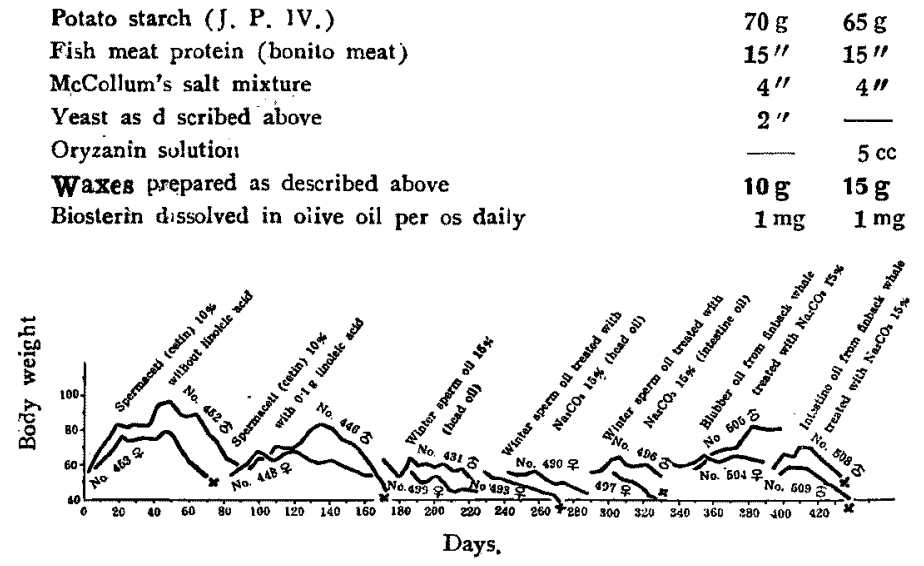

Fig. 9. The growth curves of the rats fed on diets containing purified whale oils.

Besides, a little linoleic acid was added to each diet, because it was proved to be an indispensable food factor, the absence of which causes a disease like avitaminosis.

From the above experiments it can be seen that the pure waxes have no noticeable nutritive value upon rats, and seborrhoea seems sometimes to be produced by other fats or oils which contain waxes either in small amount or free from it (Fig. $9 \sim 14$ ).

\section{(III) Experiments with fatty alcolools.}

Pure waxes had neither any pronounced nutritive value upon rats, nor seemed to produce seborrhoea. So, the authors carried out some experiments with purified fatty alcohols prepared from the head oil (sperm whale) by saponifiction. As it was shown by M. Tsujimoto and Y. Toyama, the principal components of the head oil from sperm whale are cetyl, cctadecyl and oleic alcohols, so the authors prepared these alcohols in pure state and separately tested on rats.

Cetyl alcohol: The solid waxes isolated from sperm oil was saponified with alc. $\mathrm{KOH}$ in the usual way, and the fatty acids were precipitated as Ca-soaps with hot alcoholic solution of $\mathrm{CaCl}_{2}$; filtered and the filtrate, after the removal of ethyl alcohol, was extracted with ether, and the etherial extract after washing with water was evaporated to dryness. The residue consisted chiefly of cetyl and octadecyl alcohols. It was recrystallized from acetone, and converted into the corresponding acetate by boiling with three times its amount of acetic anhydride for three hours. The acetylated products thus obtained were fractionally distilled in vacuum. The fraction boiling at 
$166 \sim 7^{\circ} \mathrm{C}(2 \mathrm{~mm})$ having the iodine value $7.4 \sim 10$ was saponified and subjected to distillation and the distillate was used for animal experiments; b p ( 3 $\mathrm{mm})=161 \sim 2^{\circ} \mathrm{C}$. In order to determine the purity of this preparation, it was again converted into acetate and the iodine value was determined with the following results,

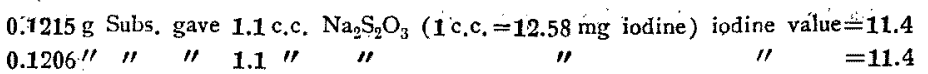

Oleic alcohol: Oleic alcohol was prepared in the similar manner as that of cetyl alcohol from the acetenn-soluble portion of the nonsaponifiable matter, separated from the liquid waxes in sperm oils. After, repeated distillation of the acetylated product, the preparation gave the following constants : b p (4 $\mathrm{mm})=180 \sim 5^{\circ} \mathrm{C}, d_{4}^{15}=0.894, n_{\mathrm{D}}^{9_{0}}=1.4532$, iodine value $=69.5 \sim 79.5$ (cal. 81.9) The preparation used in the animal experiment was also prepared from the above one by saponifying and redistilling: b $p(4 \mathrm{~mm})=178 \sim 180^{\circ} \mathrm{C}$. The purity of the preparation was confirmed by converting it into the acetate : b p $(3 \mathrm{~mm})=180 \sim 182^{\circ} \mathrm{C}$.

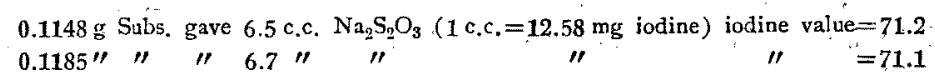

Oleic alcohol (synthetic): Synthetic oleic alcohol was prepared from ethyl oleate by reduction with $\mathrm{Na}$ in dry ethyl alcohol. After the removal of alcohol the sample thus obtained was washed with alkali, dried over anhydrous $\mathrm{Na}_{2} \mathrm{SO}_{4}$, and distilled in vacuo: $\mathrm{b} \mathrm{p}(4 \mathrm{~mm})=177 \sim 8^{\circ} \mathrm{C}$. Then, the preparation was analyzed as the acetate: $\mathrm{b} p(3 \mathrm{~mm})=180 \sim 2^{\circ} \mathrm{C}, d_{4}^{15}=0.889, n_{\mathrm{D}}^{20}=$ 1.4543 .

$0.1139 \mathrm{~g}$ Subs, gave 7.8 c.c. $\mathrm{Na}_{2} \mathrm{~S}_{2} \mathrm{O}_{3}(1 \mathrm{c} . \mathrm{c} .=12.58 \mathrm{mg}$ iodine $)$ iodine value $=86.1$

$0.1133 "$ " $7.8 "$ " " $"=86.6$

(cal. 81.9)

Feeding experiments: The feeding experiment of rats with the fat-deficient diet supplemented with $5 \%$ and $10 \%$ fatty alcohols were as follows: The diets consisted of :-

$\begin{array}{lrrr}\text { Potato starch (J. P. IV.) } & 70 \mathrm{~g} & 75 \mathrm{~g} & 80 \mathrm{~g} \\ \text { Bonito meat protein } & 15 \mathrm{~g} & 15 \mathrm{~g} & 15 \mathrm{~g} \\ \text { McCollum's salt mixture } & 4 \prime & 4 \prime \prime & 4^{\prime \prime} \\ \text { Yeast as above described } & 2 \prime & 2 \prime \prime & 2^{\prime \prime} \\ \text { Fatty alcohol (cetyl or oleic alcohol) } & 10 \mathrm{~g} & \mathbf{5 g} & \mathbf{0 g} \\ \text { Biosterin dissolved in olive oil per os daily } & 1 \mathrm{mg} & 1 \mathrm{mg} & 1 \mathrm{mg}\end{array}$

\begin{tabular}{|c|c|c|c|}
\hline Preparation used in the expt. & $\begin{array}{c}\text { Body wt, at the } \\
\text { beginn; of } t \text { he } \\
\text { expt. (av, of } 4 \text { rats) }\end{array}$ & $\begin{array}{l}\text { Body wt, at the } \\
\text { end of the expt. } \\
\text { (av. of } 4 \text { rats) }\end{array}$ & $\begin{array}{l}\text { Days of living } \\
\text { (av. of } 4 \text { rats) }\end{array}$ \\
\hline $\begin{array}{l}\text { Cetyl alcuhol } \\
\text { (the head oil f. sperm whale) } 10 \% \\
5 \%\end{array}$ & $\begin{array}{l}\therefore 9 \mathrm{~g} \\
\therefore \quad 58,5 \mathrm{~g},\end{array}$ & $\begin{array}{rr}44.0 \mathrm{~g} \\
\quad+\quad 45.5 \mathrm{~g}\end{array}$ & $\begin{array}{r}11.0 \\
\quad 10.0\end{array}$ \\
\hline
\end{tabular}




\begin{tabular}{|c|c|c|c|c|}
\hline $\begin{array}{l}\text { Oleic alcohol } \\
(\quad, r \cdots)\end{array}$ & $\begin{array}{l}10 \% \\
5 \%\end{array}$ & $\begin{array}{l}58 \mathrm{~g} \\
59 \mathrm{~g}\end{array}$ & $\begin{array}{l}44.0 \mathrm{~g} \\
45.7 \mathrm{~g}\end{array}$ & $\begin{array}{l}3.5 \\
3.7\end{array}$ \\
\hline Oleic alcohul (synthetic) & $10 \%$ & $58 \mathrm{~g}$ & $40.0 \mathrm{~g}$ & 5.0 \\
\hline Control & $.0 \%$ & $.61 \mathrm{~g}$ & $105.0 \mathrm{~g}$ & $\therefore 50.0$ \\
\hline
\end{tabular}

Moreover, in order to determine the noxious effect of oleic alcohol on rats, when fed on a diet containing butter, rats were fed on a basal diet consisting of starch $75 \mathrm{~g}$, bonito meat protein $15 \mathrm{~g}$, butter $5 \mathrm{~g}$, McCollum's salt mixture $4 \mathrm{~g}$, and commercial oryzanin solution 5 c.c.. The sample oleic alcohol $0.1 \mathrm{~g}$ was supplied for each rat per os daily.

\begin{tabular}{l|c|c|c|c}
\hline $\begin{array}{c}\text { The preparation } \\
\text { used in the expt. }\end{array}$ & Initial body wt. & $\begin{array}{c}\text { Max. body wt. } \\
\text { during the exp. }\end{array}$ & $\begin{array}{c}\text { Body wt. } \\
\text { at the end }\end{array}$ & $\begin{array}{c}\text { Daration } \\
\text { for expt. }\end{array}$ \\
\hline $\begin{array}{l}\text { Oleic alcokol } \\
\text { (the head oil } \\
\text { sperm whale) }\end{array}$ & $61 \mathrm{~g}$ & $66 \mathrm{~g}$ & $63 \mathrm{~g}$ & 20 (days of living) \\
\hline Control & $57 \mathrm{~g}$ & $63 \mathrm{~g}$ & $53 \mathrm{~g}$ & $21(\quad$ " \\
\hline
\end{tabular}

From the above result, it was confirmed that free fatty alcohols especially oleic alcohol gave toxic effects upon animals.

(IV) Injection experiments with oleic alcohol.

This experiment was conducted with the object of determining the possible role of oleic alcohol in the production of seborrhoea in rats fed on the diet supplied with sperm oils. 2 c.c. oleic alcolol or its acetate prepared from the sperm oil was injected to the peritoneal cavity of rats which were previously fed on an adequate diet. No seborrhoea was produced in any of the rats ( 4 rats); and three of them died after 10 40 hours and the last one injected with 2 c,c. oleic acetate died after 6 days. So it was also concluded that oleic alcohol itself would not produce seborrhoea in rats.

(V) Effect of linoleic acid upon seborrhoea of rats supplied with sperm whale oils.

An additional experiment was repeated to see the effects of linoleic acid and yeast on the sick rats, because they were recently recognized to be an indispensable food factor like vitamins. Rats were fed on the similar diet as above described: potato starch $65 \mathrm{~g}$, fish meat protein $15 \mathrm{~g}$, McCollum's salt mixture $4 \mathrm{~g}$, dry yeast extracted with ether $2 \mathrm{~g}$, sperm whale oil or finback whale oil $15 \mathrm{~g}$, and in addition to the basal diet biosterin $1 \mathrm{mg}$ and 
pure linoleic acid* $50 \sim 100 \mathrm{mg}$ were supplied to every rat per os daily. The rats given the head oil from sperm whale exhibited seborrhoea after 3 weeks; but on the contrary, the one given the intestine oil from sperm whale and finback whale oils was not observed to show the skin symptom for the entire feeding period of about 100 days. (Fig. 15 16).

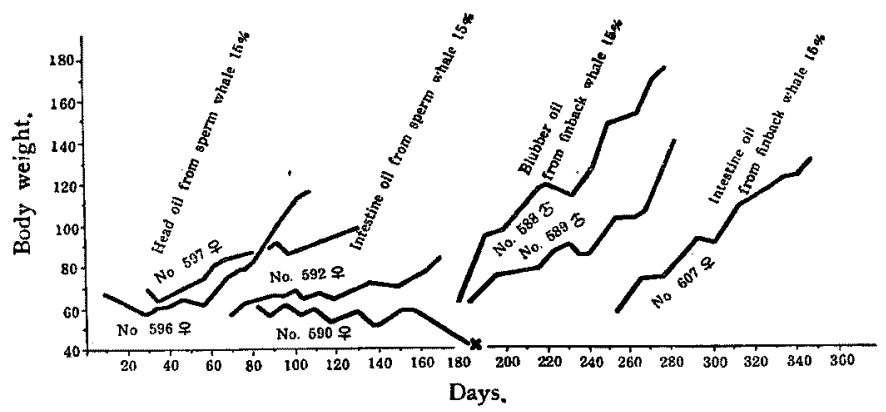

Fig. 15 The growth curves of rats fed on diets containing $15 \%$ sperm whale or finback whale oils, supplemented with a little linoleic acid and dry yeast,

\section{Summary}

1. The sperm whale oils produced seborrhoea in rats and exhibited the retarding action upon the growth of rats. Finback whale oils (especially the intestine oil), on the contrary, indicated a pronounced nutritive value.

2. In order to determine whether waxes might exhibit any nutritive activity in rats, the head oil from sperm whale was freed from spermaceti (cetin) at a temperature of $0 \sim 5^{\circ} \mathrm{C}$, and expressed oil was used as the sample of winter sperm oil for investigation. Moreover, the above four kinds of oils were separately treated with $\mathrm{Na}_{2} \mathrm{CO}_{3}$ in boiling water, and the refined oils so obtained were used for the experiments. Pure waxes prepared from sperm oil when given per os did not show the said symptom, especially when a little linoleic acid and dry yeast were administered with the waxes; so that, seborrhoea developed in rats fed on the diets containing large amount of sperm oils does not seem to be due to the high content of waxy substances in the materials.

3. Fatty alcohols especially unsaturated fatty alcohols like oleic alcohol which is a component of sperm whale waxes, have marked toxic property, but do not produce seborrhoea in rats when given per os or injected. As the waxes as such had no noxious effect, it was concluded that the waxes were not assimilated by the animals; otherwise, the diet containing sperm

* Pure linoleic acid was specially prepared by the present author from soy bean oil by the bro nination method. 


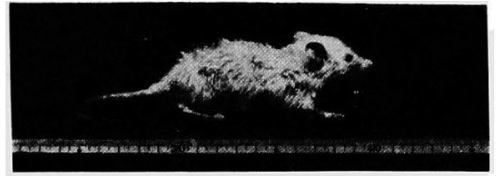

Fig. 2-Head oil from sperm whale $15 \%$ No, 363. body wt. $49 \mathrm{~g}$ (after 9 days)

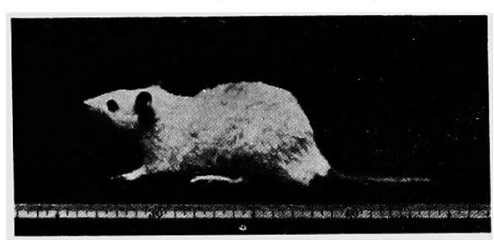

Fig. 4-Blubber oil from finback whale $15 \%$ No. 353. body wt. $102 \mathrm{~g}$ (after $\mid 4 \mathrm{~s}$ days).

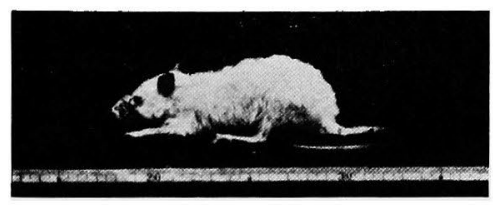

Fig. 6-Blubber oil from finback whale $15 \%$ No. 351 . body wt. $64 \mathrm{~g}$ (after 75 days).

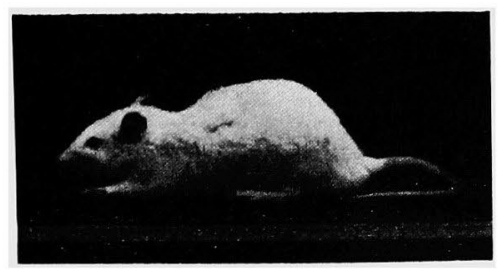

Fig. 10-Spermaceti (cetin) $10 \%$ added with yeast $2 \%$ No. 452 . body wt. $89 \mathrm{~g}$ (after 52 days).

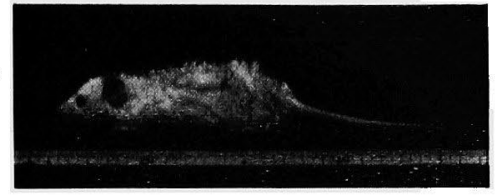

Fig. 3-Intestine oil from sperm whale $15 \%$ No. 390 . body wt. $55 \mathrm{~g}$ (after 11 days).

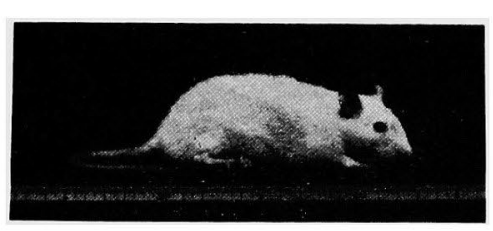

Fig. 5-Intestine oil from finback whale $15 \%$ No. 355 body wt. $121 \mathrm{~g}$ (after 48 days).

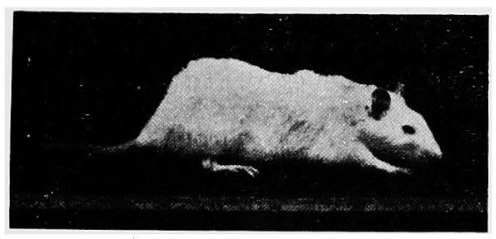

Fig. 7-Intêstine oil from finback whale $15 \%$ No. 355. body wt, $152 \mathrm{~g}$ (after 75 - days).

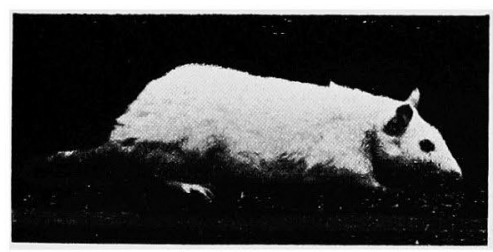

Fig. 8-Intestine oil from finback whale $15 \%$ No. 355. body wt. $180 \mathrm{~g}$ (after 128 days). 


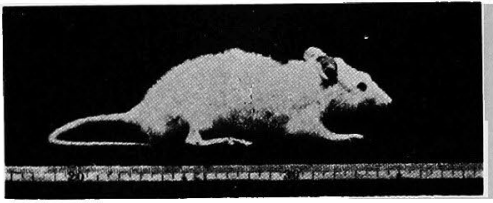

Fig. 11-Spermaceti (cetin) 15\% Oryzanin $5 \mathrm{cc}$ added No, 428 body wt. $65 \mathrm{~g}$ (after 30 days).

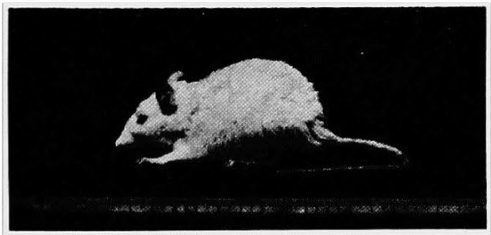

Fig. 13-Intestine oil from sperm whale $15 \%$ treated with $\mathrm{Na}_{2} \mathrm{CO}_{3}$ Oryzanin $5 \mathrm{cc}$ added No. 496 body wt. $61 \mathrm{~g}$ (after 30 days).

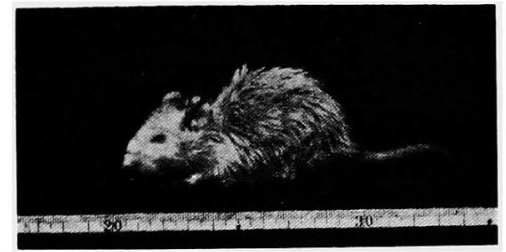

Fig. 16-Head oil from sperm whale $15 \%$ added with linoleic acid (2 drops) and yeast No. 595 body wt. $53 \mathrm{~g}$ (after 3 weeks).

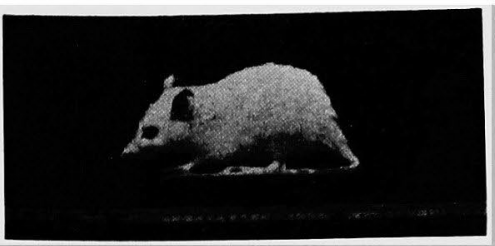

Fig. 12-Head oil from sperm whale 15\% Oryzanin $5 \mathrm{cc}$ added No. 490 body wt. $51 \mathrm{~g}$ (atter 30 days).

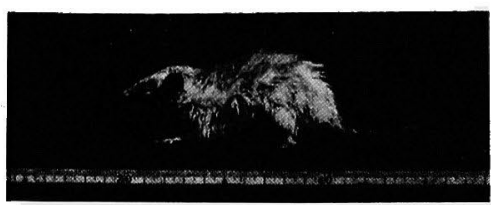

Fig. 14-Blubber oil from finback whale $15 \%$ treated with $\mathrm{Na}_{2} \mathrm{CO}_{3}$ Oryzanin $5 \mathrm{cc}$ added No. 504 body wt. $62 \mathrm{~g}$ (after 50 days).

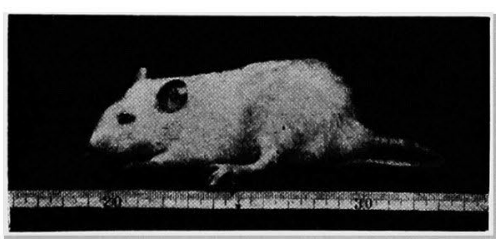

Fig. 17-Intestine oil from sperm whale $15 \%$ added with linoleic acid ( 2 drops) and yeast No. 592 body wt. $69 \mathrm{~g}$ (after 5 weeks). 
whale oils in sufficient quantity should give more noxious effect.

Moreover, the author has observed that diets supplied with fat consisting of ordinary glycerides have frequently produced the similar symptom in the skin of rats; and on the other hand, that the symptom was prevented by the addition of a small amount of yeast and linoleic acid even when given sperm oils.

The author expresses his sincere thanks to Prof. U. Suzuki for his kind advice and encouragement throughout the work. The author is also indebted to Mr. K. Tago and to the Tóyo Hogei Kaisha for the kind supply of reliable whale oils in fresh condition.

\title{
Reference
}

(1) J. Snc. Chem, Ind. Japan, Suppl. 24, 11 15, (1921).

(2) J. Soc. Chem. Ind. Japan, Suppl. 28, 13 16, (1925); 30, 137 8, (1927).

\section{On the Ergosterin Content of Various Edible Mushrooms in Japan.}

\author{
By Midzuho Sum.
}

(leceived Feibruary 17, 1933.)

Some years ago(1), the author had isolated ergosterin from Cortinellus Shiitake, carefully studied its chemical nature, converted it into vitamin $\mathrm{D}$ by irradiation with ultra-violet rays, and proved it to be identical with the preparations obtained from ergot or from yeast by other authors. Later, it was observed that this substance is widely distributed in many other mushrooms, either cultivated or grown wild in various districts of Japan. As these mushrooms are not only consumed to a large extent as a favourite food by our people but also some of them are exported to other countries in a notable amount, it seems desirable, from the stand point of nutrition and public health, to determine their ergosterin content quantitatively. As there is not yet reliable method known for this purpose the author has adopted the digitonin method which is commonly used for the determination of sterins.

Since there is no noticeable amount of sterin other than ergosterin, detected in these fungi, the author presumes that the result obtained by the above method will suffice to represent the approximate amount of ergosterin. 